\title{
"Sobre o rumo da literatura de revista nos anos de 1834 e 1835": tradução do polêmico artigo de N. V. Gógol na revista "O Contemporâneo", de A. S. Púchkin
}

Fabrício Yuri de S. Vitorino*

Resumo: Em 1836, a revista "O Contemporâneo", de A. S. Púchkin, publica um ácido e extremamente crítico artigo apócrifo. Creditado tardiamente a Nikolai Vassílievitch Gógol, "Sobre o rumo da literatura de revista nos anos de 1834 e 1835" apresenta o cenário da crítica literária da época. Neste artigo, a primeira parte do longo texto é apresentada em tradução direta do original, em russo.

Palavras-chave: Gógol, Púchkin, O Contemporâneo, literatura russa, crítica literária

\section{Introdução}

Em 1836, em plena alvorada do cenário das revistas literárias na Rússia, Nikolai Vassílievitch Gógol é convidado por Aleksandr Serguéievitch Púchkin a participar do elenco de escritores e intelectuais de sua aguardada publicação - "O Contemporâneo"'. O almanaque, que levava o nome do principal poeta e escritor russo na capa, fora pensado para figurar como contraposto ao principal veículo da

\footnotetext{
* E-mail: fabyuri@gmail.com

1 Современник (Sovriemennik), revista russa publicada trimestralmente durante 1836-1846, em São Petersburgo, onde foi publicada boa parte da produção do poeta, como "Cavaleiro de Bronze" e "A Filha do Capitão”. Participaram do Современник inúmeros grandes nomes da literatura russa do século XIX, como N. V. Gogol e A. I. Turguêniev.
} 
época, a "Biblioteca para leitura", editado por Ósip-Iulián Ivanovich Senkóvski² e que almejava um grande público.

Mas, ao contrário do que era relativamente comum nas revistas literárias da época, "O Contemporâneo" de Púchkin não trouxe, evidente, em seu primeiro número um programa que fosse nortear sua linha editorial. Não se sabia se a publicação abordaria análises históricas, factuais, se ficaria restrita à crítica literária ou mesmo se traria ensaios, poesias, contos ou prosa de novos ou já consagrados autores. E isto figurou como uma das grandes questões acerca de "O Contemporâneo".

No volume de estreia, o autor de "Eugene Onegin" dispõe os textos de modo a dar certa evidência à crítica-programática "Sobre os rumos da literatura de revista nos anos de 1834 e 1835". Era o primeiro texto em forma de prosa, após duas poesias e uma peça. Um texto extremamente oral, veloz, eloquente, que sobrevoava todo o cenário editorial do início do século 19 na Rússia, associando nomes, publicações, estratégias mercadológicas e análise de público-alvo. Com críticas mordazes e extremamente bem postadas, "Sobre os rumos..." estava exposto, ainda que subliminarmente, para ser entendido como o programa da revista literária de Púchkin. O texto foi impresso sem a assinatura de N. V. Gógol (ainda que, nos primeiros números de "O Contemporâneo", seu nome conste como responsável pelo texto). O cenário estava montado e, ainda que sutilmente, era inequívoca a disposição de Púchkin de exibir os talentos de seu mais novo amigo.

No entanto, diferentemente de seus contemporâneos (russos ou estrangeiros) na crítica literária, Gógol transita com absoluta fluidez entre disciplinas como a história e a filosofia, sempre pontuadas por muita ironia, e carregadas por aspectos pedagógicos e científicos incomuns aos demais críticos. No artigo "Sobre os rumos...", conforme apontou Ivan Panáev, Gógol "provocou um grande barulho na literatura, e causou uma significativa boa impressão no público"3. Já para Vissarion Belínski, o artigo de Gógol é "um dos mais interessantes do programa e reflete a alma e o direcionamento da nova revista"4.

Para Púchkin, a publicação do artigo de Gógol teve, sem dúvida, um aspecto tático: apócrifo, o texto foi entendido facilmente como programa e linha editorial. Dois números depois, "O Contemporâneo" publica uma "Carta ao editor", de um suposto leitor da cidade de Tveri, que fazia contestações ao artigo de Nikolai Vas-

2 Senkóvski (1800-1858) - Russo-polonês, também conhecido como “"Barão de Brambeus”. Orientalista, tradutor, ensaísta e fundador da primeira publicação de massa da Rússia, a "Biblioteca para leitura".

3 Panáev, I. I. Literaturnye vospominania (memórias literárias). Goslitzdat, 1960.

4 Belinski, V. G. Neskolko slov o sovriemenike (algumas palavras sobre "O Contemporâneo"). 
silievitch. Escrito em fantasia pelo próprio Púchkin, o texto fora respondido pelo próprio poeta - desta vez assinado - e trazia a posição final do editor: "Sobre os rumos da literatura de revista não é e nem poderia ser a linha editorial da revista".

"Sobre os Rumos da literatura de revista nos anos de 1834 e 1835" é, provavelmente, um dos últimos trabalhos de Gógol na Rússia antes de partir para uma vida de dez anos no exterior. Sua jornada começa em 1830, quando começa a colaborar regularmente com o periódico "Notas da pátria", onde publicou sua primeira prosa, "A Noite de São João". A partir daí, conheceu grandes nomes da intelectualidade russa, como V. A. Júkov e P. A. Pletniev, além do próprio Púchkin. Publica em 1831-32 "Noites na Granja ao Pé de Dikanka" e, em 1835, "Mirgorod", "Arabescos", "Avenida Niévski", "Taras Bulba" e "Diário de um louco".

O presente artigo traz a tradução para o português da primeira metade de "Sobre os rumos da literatura de revista nos anos de 1834 e 1835", diretamente do russo. O texto de Gógol é dividido em duas partes - na primeira delas, o autor de "O Capote" faz uma análise das revistas literárias da época, de seus fundadores, editores e corpo editorial. $\mathrm{Na}$ segunda, o autor se aprofunda nas críticas.

\section{Sobre o rumo da literatura de revista nos anos de 1834 e 1834 (Nikolai Gógol)}

Literatura de revista é a literatura viva, fresca, loquaz, delicada, de modo que indispensável às esferas das ciências e artes, como meio de comunicação para os estados, como feiras e bolsas para compradores e negociadores. Ela determina os gostos da massa, direciona e põe em marcha todas as publicações viabilizadas pelo mundo dos livros, que, sem essa literatura de revista, seria um "capital morto" em todos os sentidos. Ela é rápida, uma caprichosa troca de múltiplas opiniões, uma conversa viva entre todas as máquinas tipográficas, sua voz é a verdadeira representante da opinião de toda uma época e século. Essa opinião, aliás, desapareceria silenciosamente sem a literatura de revista. Ela, por bem ou por mal, domina e arrasta para sua área de influência 90\% de tudo o que é feito nas áreas da literatura. Tantas são as pessoas que julgam, falam e opinam graças ao fato de que todas essas avaliações lhes chegam praticamente prontas. Essas pessoas não opinariam, falariam ou julgariam se dependessem de si próprias. Desta forma, a literatura de revista, em qualquer circunstância, tem o direito de demandar a mais perscrutadora atenção.

Pode ser que há muito em nosso país não se tenha percebido tão fortemente a ausência de produções literárias em revistas, bem como de um movimento vivaz 
contemporâneo, como nos últimos dois anos. A falta de originalidade tem sido a principal característica de grande parte das edições periódicas. Muitas revistas antigas foram encerradas, outras se arrastam vagarosamente; das novas, além da "Biblioteca para leitura" e o recente "Observador moscovita", nada foi mostrado, exatamente assim como nada em nenhum lugar deste nosso tempo, de qualquer atividade que requeira alguma atividade intelectual. Ainda assim aumentou em muito sua quantidade de leitores. Mesmo que esta época seja tão pobre, ainda assim ela também tem direito à nossa atenção, assim como qualquer outra que estivesse a colocar em ebulição algum movimento, porquanto também pertencente à história das nossas letras. Os leitores, assim, têm todo o direito de reclamar da pobreza e do jejum de visões de nossas revistas: o "Telégrafo"7 há muito perdeu seu tom incisivo, o qual lhe conferia um caráter belicoso em relação a outras publicações de São Petersburgo. O "Telescópio"» encheu-se de matérias nas quais nada há de fresco, palpitante ou atual. Neste meio tempo, o vendedor de livros Smirdin' ${ }^{9}$ há muito conhecido por sua atividade e honestidade, embora sozinho, para a vergonha de outros de seus camaradas míopes, demonstrou empreendedorismo e com suas iniciativas colocou em movimento o mercado livresco. $\mathrm{O}$ vendedor de livros tomou a decisão de editar revistas mais vastas, amplas, enciclopédicas, conquistar todos os literatos quantos houver na Rússia, e de obrigá-los a participar de iniciativa. No programa estavam exibidos nomes de praticamente todos os nossos escritores. $\mathrm{O}$ professor de literaturas árabes, senhor Senkóvski, foi chamado a ser o responsável pela revista. A ele se juntou o editor, senhor Gretch ${ }^{10}$, muito conhecido pela edição constante de duas revistas: "A abelha do norte"

5 Revista literária mensal editada em São Petersburgo, entre 1834 e 1865. (N. do T.)

6 Revista histórico-literária bimestral editada em Moscou, entre 1835 e 1839. (N. do T.)

7 Tida como a primeira revista literária, de formato “enciclopédico", da Rússia. Editada entre 1825 e 1834 por Nikolai Polevói, era publicada a cada duas semanas. (N. do T.)

8 Revista literária quinzenal, editada em Moscou entre os anos de 1831 e 1836. Nela, publicaram textos A. S. Púchkin, F. I. Tiútchev, V. G. Belínski e P. Ia. Tchaadáev. (N. do T.)

9 Aleksandr Filipovitch Smirdín (1795-1857), editor e negociador do ramo de livros, uma das mais importantes figuras no desenvolvimento da literatura impressa da Rússia. (N. do T.)

10 Nikolai Ivánovitch Gretch (1787-1867), escritor, editor, tradutor, jornalista, tradutor e filólogo russo. (N. do T.)

11 Revista político-literária editada em São Petersburgo entre 1825 e 1864, fundada por Faddei Bulgárin. Um dos veículos mais importantes da história literária da Rússia. (N. do T.)

12 Revista político-literária, editada em São Petersburgo entre 1812 e 1852. Junto com a "Abelha do norte", teve um papel fundamental na fundação e desenvolvimento da literatura e do pensamento político na Rússia. (N. do T.) 
Não sabemos, porém, se eles mesmos se ofereceram para as posições ou se foram convocados pelo senhor Smirdin, mas por qualquer que tenha sido a circunstância, o vendedor de livros, por opinião geral, agiu deveras imprudentemente. Tendo tido sucesso em arregimentar para sua edição tal quantidade de literatos, ele deveria tê-los submetido ao crivo de escolha do editor.

Então, ninguém aparenta ter se ocupado da importante questão: deve a revista ter apenas um tom, um posicionamento pré-definido, uma opinião representativa, ou ser o local de depósito de todas as correntes e orientações. Uma revista desta natureza apresenta-se de forma surda, com declarações prosaicas, de que a crítica será sempre leal, segura, imparcial, alheia a quaisquer personalidades e impessoalidades - juramento, aliás, que presta qualquer jornalista. Com a publicação do primeiro livro, o público claramente percebe que na revista predomina um tom: as opiniões e pensamentos são um só, e que os nomes dos escritores, cuja brilhante enumeração preencheu meia página da folha de rosto, foi tomada apenas de aluguel, para entretenimento e gozo da maior parte dos assinantes.

De sua parte, o vendedor de livros Smirdin cumpriu tudo que o público tinha o direito de exigir. Aquela mesma honestidade, que sempre o diferenciara, fora mostrada por ele na edição da revista. O periódico era publicado com uma regularidade incomum: os assinantes recebiam, a cada primeiro dia útil de mês, um grosso livro - tamanho que, até pouco tempo atrás, não poderia ter sido impresso por nenhuma gráfica de nosso país no período de dois meses. Em vez da prometida quantidade de 18 páginas por mês, eram publicadas, por vezes, duas vezes mais. Mas agora analisemos se era entregue tudo o que fora prometido pelo editor na disposição da revista. O principal responsável e mola que impulsionava toda a revista era o senhor Senkóvski. O nome do senhor Gretch foi utilizado apenas proforma, de modo que nenhuma ação foi notada de sua parte. O senhor Gretch já se tornou, há muito, editor honorário e indispensável de qualquer publicação periódica tal como um honroso senhor de idade é convidado para padrinho de casamento em qualquer cerimônia. Mas qual é o objetivo da redação desta revista, qual problemática ela se propunha a resolver? Aqui, a contragosto, nós refletimos muito sobre isso e, sem dúvida, também o fez o leitor. No programa, o senhor Senkóvski nada diz sobre qual foi o caminho escolhido, qual foi a meta traçada. Todos viram apenas como ele germinou imperceptivelmente o primeiro número e como, ao seu final, ele mostrou-se como seu verdadeiro condutor.

Por outro lado, não é possível reclamar disto: e sabe-se que, para o jornalista, é imperativo possuir um tom afiado e, por vezes, até petulante (o que nós, no entanto, não aprovamos, muito embora a nós seja sabido que, com tal qualidade, os jornalistas sempre conseguem conquistar a opinião da massa), mas baseado em 
qual preferência as atenções se voltaram para seu fundador, qual opinião dele se sobrepôs a todo o resto, a que são direcionadas suas preferências, foram ou não percebidos seu códex, de quais pessoas é preciso tirar as características para que se destaque nele a originalidade e seja possível definir sua fisiognomia ${ }^{13}$ ?

Tendo lido tudo o que foi disponibilizado nesta revista, seguido por todas as palavras ditas por eles, é involuntário ficar surpreso: o que é isso? O que motivou essa pessoa a escrever? Nós vemos alguém que se apropria de dinheiro que não lhe é dado gratuitamente, que trabalha incansavelmente com o suor no rosto, que tem extremo cuidado com suas matérias, e que eventualmente corrige textos de outros, que pode ser descrita em uma palavra: incansável. Para que afinal toda essa atividade? Vamos analisar o editor em todos os gêneros de sua obra e iremos dizer algumas palavras sobre as principais qualidades de suas matérias. Isso é, de todas as maneiras, necessário.

O senhor Senkóvski atua em seu jornal como crítico, narrador, erudito, satírico, arauto das notícias e mais e mais. Apresenta-se na forma de Brambeus ${ }^{14}$, Morozov, Tiutiundja Olga, A. Belkin, e, por fim, como si próprio. Como erudito, o senhor Senkóvski viabilizou uma enorme matéria sobre as sagas, matéria essa baseada em hipóteses, não próprias, mas sequestradas exitosamente de diferentes e mediocremente lidos livros, hipóteses absolutamente pertinentes à história da Rússia. Tais sagas o perspicaz Shletser ${ }^{15}$, que até hoje não possui equivalentes em força e profundidade de ponto de vista crítico, considerou como fábulas, indignas de qualquer atenção maior; tais sagas ele coloca como pedra fundamental da história russa sem prover qualquer evidência, sob o ponto de vista da crítica confiável: ele de nenhuma forma atribuiu a elas uma real e contundente evidência ou sequer mérito. As sagas são a essência da forma poética popular, com um enorme papel na história. Esta matéria, recheada de figuras retóricas, agradou a bons, porém limitados, leitores, e o senhor Bulgárin até mesmo escreveu uma crítica, na qual colocava o senhor Senkóvski num patamar mais alto que Shletser, Humboldt e quaisquer outros eruditos que tenham existido. Outra evidência da extrema pretensão do senhor Senkóvski e de sua verdadeira intenção é o Oriente. Aqui ele sempre eleva o tom de voz, e sempre que é publicado algo sobre o Oriente, ou algo sobre o Oriente

13 Ciência que permite, através dos traços físicos da pessoa, prever o seu carácter psicológico. (N. do T.)

14 Barão de Brambeus, um dos pseudônimos de O. I. Senkóvski. (N. do T.)

15 August Ludwig von Schlözer (1735-1809), historiador alemão que lançou as bases para a historiografia da Rússia. E entrou em conflito com M. V. Lomonosov acerca do tema. (N. do T.) 
é lembrado, ainda que seja em verso, ele encoleriza-se e sustenta que o autor não deve julgar o Oriente, que o autor não conhece o Oriente. A palavra dita com o coração é perdoável no homem que é apaixonado pelo seu tema e que, além de tudo, vê o quão pouco sobre o assunto sabem os outros. Esse homem deve, afinal, consolidar-se como autoridade no tema. O senhor Senkóvski certamente teria de publicar algo sobre o Oriente. É difícil levar a sério a palavra de um homem que nada fez, ainda mais quando sua argumentação é frágil e tem a alma impregnada de impaciência; assim como em alguns de seus textos sobre o Oriente são percebidos os mesmos defeitos que ele incansavelmente aponta nos outros. Nada de novo foi dito nesses trechos sobre o Oriente, sequer um claro aspecto, um raciocínio embasado, uma formulação genial! Não se deve negar que o senhor Senkóvski tenha evidências; pelo contrário, percebe-se que ele leu muito, mas em nenhum lugar é percebida essa motivação, essa força cavalheiresca que o direcionaria a qualquer que fosse o objetivo. Todas essas percepções são encontradas nele em alguma forma efervescente, contradizendo-se umas às outras, e não sobrevivem entre si. Analisamos suas opiniões, sobretudo aquelas que se relacionam com as correntes atuais da literatura de belas letras. Na crítica, o senhor Senkóvski mostra ausência de qualquer opinião, de forma que nenhum dos leitores pode dizer, provavelmente, que a crítica lhe agradou e preencheu sua alma, que lhe atingiu os sentimentos: nas suas resenhas não há argumentação positiva ou negativa, não há nada. Aquilo que hoje lhe apetece amanhã lhe servirá como objeto de zombaria. Ele, de início, colocou o senhor Kukolnik ${ }^{16}$ nas mesmas fileiras de Goethe, e ele mesmo declarou, que o fizera isso apenas por ter chegado sozinho a tal conclusão. Deste modo, suas resenhas não têm por objetivo convencer ou emocionar, mas simplesmente ser uma consequência de seu estado de espírito. Walter Scott, este grande gênio, cuja obra imortal aquece a vida com enorme amplitude, bom, Walter Scott é chamado de charlatão. E isso foi lido pela Rússia, sobre isso falaram pessoas letradas, que já haviam lido Walter Scott. Pode-se acreditar que o senhor Senkóvski disse isso sem quaisquer segundas intenções, apenas por amargura, uma vez que ele nunca reflete sobre o que fala, e, na próxima matéria, já não lembra o que fora escrito na anterior.

Em suas análises e críticas, o senhor Senkóvski também nunca comentou sobre o caráter interno das composições escolhidas, não definiu factíveis e acurados traços de seus méritos. Sua crítica era composta ora de elogios incondicionais, nas quais o resenhista com toda sua alma deleitava-se com as próprias frases, infâmias que eram proferidas com uma estranha obstinação. É composta de migalhas, 
definida por três ou quatro sentenças e zombarias. Nada era dito sobre qual seria o real objetivo do autor com a composição escolhida, como isso seria atingido e, caso não conseguisse fazê-lo, como poderia. Acima de tudo o senhor Senkóvski ocupava-se da análise de diferentes brigas literárias, variações de todo tipo de literatura vazia. Sobre elas, debochava, zombava e demonstrava aquela originalidade que tanto agrada a alguns leitores. Por fim, emendou um caso inteiro sobre dois pronomes: сейи оный ${ }^{17}$, que tanto lhe pareciam, sabe-se lá o motivo, despropositados na língua russa. Sobre essas preposições foram escritos por ele tratados inteiros, bem como matérias, que discorriam sobre qualquer motivo indefinido, sempre encerrando com o argumento de que essas preposições são completamente grosseiras. Isso nos faz lembrar um velho processo de Tredyakov sobre a letra "ijitsa"18 e das dezenas de variações do "i", que por fim veio ganhar o apoio de um professor. O livro, no qual o senhor Senkóvski tomou conhecimento destes dois excertos, foi especialmente declarado como escrito com um estilo estúpido.

Suas composições próprias, contos e coisas afins, foram apresentadas sob a assinatura de Brambeus. Tais narrativas e matérias similares a contos, a seus próximos, imitadores involuntários de quaisquer escritores franceses contemporâneos, causaram espanto geral, graças ao fato de que o senhor Senkóvski menosprezou toda a literatura francesa contemporânea. É inconcebível como, desta forma, ele pode demonstrar tão pouca sagacidade e ao fazê-lo, menosprezar e tratar como ingênuos todos os seus leitores. Também é incompreensível o motivo que o levou a considerar alguns de seus textos como fantásticos. A ausência de qualquer veracidade, verossimilhança ou caráter crível não são suficientes para caracterizar algo como literatura fantástica. Os textos fantásticos do Barão de Brambeus nos remetem a livros, que não nos fariam perder muito tempo lendo: "Не Аюбо - не слушай, а кгать не мешай" ${ }^{19}$, е outros do tipo. Tal irresponsabilidade demonstra ainda menos compromisso com a argumentação de qualquer outro raciocínio. Os leitores mais experientes perceberam isso como um extraordinário conjunto de plágios, feitos às pressas, a toda velocidade: o autor mal se preocupou em concatenar ideias. Tudo o que fazia sentido nos originais, nas cópias foi mostrado sem qualquer lógica aparente.

Tais foram os trabalhos e atos do chefe da "Biblioteca para a leitura". Nós honrosamente precisamos mencionar sobre eles alguns aspectos, uma vez que ele

17 Forma arcaica do pronome russo "tal", " este". (N. do T.)

18 Letra do alfabeto do eslavo antigo (V). (N. do T.)

19 “As aventuras do Barão Munchausen”, de Rudolf Erich Raspe. (N. do T.) 
é o único regulador na "Biblioteca para leituras" e suas opiniões foram espalhadas incrivelmente rápido, junto com quatro mil exemplares da revista, por todas as casas da Rússia.

É inconcebível para uma revista, editada e publicada sob tais condições, produzida pelo vendedor de livros Smirdin, ser ruim. Mérito a ele por ter editado em um esquema grandioso, com êxito, revistas grossas. Essa foi a melhor notícia para os assinantes, ainda mais para os moradores de nossas cidades e do interior. $\mathrm{Na}$ "Biblioteca" encontravam-se traduções de interessantes artigos de revistas estrangeiras, e no ramo das poesias apareciam nomes que iluminavam o parnaso russo. Mas, com certa frequência, a melhor seção da "Biblioteca" era a mistura, que trazia em si muitas notícias frescas sobre variados temas. Era uma seção viva, típica de tais almanaques. A prosa de alto nível, original e traduzida, em contos e demais formas, acabava sendo de muito mau gosto e baixa qualidade. Na "Biblioteca para leitura" acontecia sempre a mesma coisa, algo até então inédito na Rússia. Seu chefe passou a corrigir e reescrever praticamente todas as matérias impressas no veículo, e é curioso que ele próprio declarava isso, de forma satisfatória e aberta: "Aqui - dizia ele - na 'Biblioteca para leituras', não é como nas outras revistas: não deixamos nenhum conto da forma crua, reescrevemos praticamente tudo: por vezes fazemos, de duas, uma, por vezes até de três, e as matérias melhoram significativamente com nossas intervenções". Tal estranha tutela não fora vista na Rus ${ }^{20}$ até então.

Muitos escritores começaram a ter receio de que o público não aceitaria matérias, que porventura não fossem publicadas sem assinatura ou ainda sem algum pseudônimo, por conta própria, e por isso começaram a declinar da participação na edição de tais revistas. O número de integrantes diminuiu de tal forma que, no ano seguinte, os editores não conseguiram montar uma lista tão grande de nomes, e divulgaram cegamente que participavam os melhores literatos, mas sem definir quais eram. A revista não mudou em grandeza e projeto, mas as matérias notadamente começaram a ficar piores; percebia-se um esforço menor. Cada vez menos lia-se a "Biblioteca" nas capitais, mas ainda muito nas províncias, e sua opinião começou a voltar-se para esse fato rapidamente. Vamos agora nos voltar para outras revistas.

A "Abelha do Norte" fechou sua linha editorial no noticiário oficioso, e desta forma cumpriu seu papel. O periódico distribuía em suas páginas fatos po-

20 Nome que define o conceito de povo, língua e região dos estados medievais da Rus Kievana. Na Europa, era conhecida como "Ruthenia", do século 11 em diante. (N. do T.) 
líticos, estrangeiros e nacionais. O editor, senhor Gretch, conduziu o almanaque por uma correção impressionante: ele sempre saía ao devido tempo, mas nunca trouxe consigo qualquer importância literária, não tinha nenhum tom relevante e não demonstrava ter qualquer "pulso forte", que guiasse sua opinião. A "Abelha do Norte" funcionava como uma espécie de lata de lixo, na qual eram jogados materiais sobre quaisquer assuntos que interessassem ao editor. As análises de livros, quase sempre favoráveis, eram escritas por amigos, e muitas vezes pelos próprios autores. Na "Abelha do Norte" diversos desconhecidos, sem dúvida nenhuma jovens, treinavam a ironia de suas penas, ocultos sob variadas assinaturas, uma vez que as matérias expressavam bastante audácia. Eles atacavam na maioria das vezes até mesmo o mais indefeso dos provincianos. No que tange aos desmazelos da publicação, surgiam críticas mordazes, que, por vezes, pareciam-se umas com as outras. A principal característica das análises consistia em elogiar um livro e, ao fim, eximir-se de todos os pecados com uma ressalva: "Ademais é desejável que o referido autor corrija seus erros eventuais no que tange à língua e ao vocabulário" ou "Um bom livro demanda um bom editor", e coisas do tipo, com as quais os autores frequentemente se incomodavam e reclamavam dos critérios do resenhistas. Os livros normalmente eram dissecados pelos mesmos analistas que escreviam as notícias sobre novas fábricas de tabaco abertas na capital, sobre cosméticos e afins; tais notícias por vezes demonstravam bastante originalidade, e seus chistes entregavam sagazes e bem-educadas pessoas que, sem dúvida, possuíam motivos bastante razoáveis para estarem satisfeitos com os fabricantes. Por fim, da "Abelha do Norte" não havia mais nada que se demandar: ela sempre foi uma lúcida agenda de divulgação diária, e seus objetivos eram convidar o público. Porém, julgar e analisar, ela deixava a cargo mesmo público.

A revista que trazia o nome "Filho da Pátria e Arquivo do Norte"21 era praticamente invisível por todo esse tempo. Sobre ela ninguém falava, para ela ninguém escrevia, muito embora ela saísse regularmente todas as semanas e trouxesse impresso um enorme programa em suas páginas, tal como dificilmente poderia ser visto à época. No "Filho da Pátria" (segundo o programa) haveria arqueologia, medicina, jurisprudências, estatística, história russa e história geral, filologia russa, filologia estrangeira e filologia geral, geografia, etnografia e muito mais. É inevitável

21 Com a prisão dos “dezembristas”, em 1825, e a mudança da política na Rússia, o número de colaboradores do "Filho da pátria" caiu consideravelmente. Assim, a revista passou a ser dirigida por F. I. Bulgárin, que acertou a fusão e colaboração com N. I. Gretch. Em 1829, as duas revistas, "Filho da Pátria" e "Arquivo do Norte" se uniram e formaram uma só: "Filho da Pátria e Arquivo do Norte: revista de literatura, política e história contemporânea". (N. do T.) 
não se espantar ao ler tal horrível programa, e pensar que tal edição enciclopédica gigante foi capaz de existir. E absolutamente existiu: era impresso um magro e deveras fino livretinho, com apenas três páginas, iniciando-se com uma matéria sobre uma doença qualquer, algo que nem mesmo os médicos haviam lido. Um texto crítico, que muito embora parecesse vívido e contemporâneo, não trazia em si qualquer substância. O noticiário político consistia em fatos secos, extraídos da "Abelha do Norte", portanto já do conhecimento de todos. Também eram publicados, aleatoriamente, contos originais que eram demasiadamente estranhos, inesperadamente curtos e completamente sem colorido. Caso aparecesse algo digno de atenção, teria passado despercebido. Os nomes dos editores Bulgárin e Gretch figuravam apenas na página de rosto, e, definitivamente, da parte deles não era vista nenhuma participação. Uma vez que a revista existia, pode-se dizer que havia leitores e assinantes. E tais assinantes eram pessoas de idade e honoráveis, que viviam nas províncias e para os quais ler qualquer coisa era tão indispensável como tirar uma soneca após o almoço ou barbear-se duas vezes por semana.

Em São Petersburgo era ainda publicada durante todo esse tempo uma revista puramente literária, liberta de quaisquer ciências indesejadas e informações importantes, não política, não estatística, não enciclopédica, entusiasta de idosos, e acima de tudo possuidora de um caráter relevante. O nome desta revista: "Desenvolvimento literário para o inválido"22. Nela eram distribuídos contos levíssimos, relatos de fazendeiros rurais sobre literatura, diálogos esses muitas vezes suficientemente prosaicos, mas por vezes com locais impregnados de mordacidade, bem próximos à verdade. O leitor, para sua surpresa, via como os fazendeiros se tornavam praticamente literatos ao final das matérias, compreendendo de coração a literatura contemporânea e temperando suas opiniões com alguma troça cáustica. Este almanaque sempre se mostrou como oposição, muito embora sua tática consista unicamente em suprimir qualquer trecho que possa demonstrar alguma leviandade jornalística e anexar, de sua parte, considerações raivosas sem muitas delongas e com ponto de exclamação. O senhor Voeikov ${ }^{23}$ era um excepcional e ativo pescador, e como pescador, sentava com a vara à beira do rio, sem perder a paciência, muito embora em sua vara aparecesse na maior parte das vezes um peixe miúdo. O editor mantinha patente uma vida estritamente literária, e o mes-

22 Revista literária e de variedades, editada em São Petersburgo entre 1831 e 1839. A tradução "Desenvolvimento literário para o inválido" foi a opção encontrada para melhor adaptar o conteúdo do veículo à língua portuguesa. (N. do T.)

23 Aleksander Fiodorovitch Voiéikov (1778-1839), poeta, tradutor, editor, jornalista e crítico literário. Membro da Academia Russa. (N. do T.) 
mo com calorosa atenção sequer retirava os olhos do mercado editorial. Eu não tenho conhecimento sobre o número de leitores de suas revistas, se eram muitos ou poucos, mas ela definitivamente valia a pena ser espiada, eventualmente.

Em Moscou, somente era editada a revista “Telescópio”, com um pequeno acréscimo de páginas, sob o título de "Rumor" ${ }^{24}$. A revista de início deu sinais de vivacidade, mas logo adoeceu, enchendo-se de matérias sem qualquer qualidade, abrindo mão de qualquer movimento literário. Era notório que os editores não dedicavam nenhuma atenção à revista e distribuíam os livretos de qualquer jeito.

O monopólio mantido pela "Biblioteca para leitura" não poderia sequer ser ameaçado por qualquer outra revista da época. Mas a "Abelha do Norte" era editada pelo mesmo senhor Gretch, nome que, algum tempo atrás, já constara na folha de rosto da "Biblioteca para leitura", como seu editor-chefe, muito embora tal cargo, como já vimos anteriormente, fosse apenas de fachada, e por isso nos pareceu natural que a "Abelha do Norte" devesse elogiar tudo o que fosse disposto na "Biblioteca", e sua força-motriz, que aparecia sob vários pseudônimos diferentes, deveria ser chamada de "Humboldt russo". E sem esse, a revista dificilmente poderia se tornar uma oponente relevante, já que era comandada pela mesma força, e diferentes literatos a acompanhavam somente para suprir suas necessidades. $\mathrm{O}$ "Filho da Pátria" deveria apenas repetir as palavras da "Abelha". Desta forma, apenas duas outras revistas poderiam levantar-se contra sua opinião. O senhor Voieikov demonstrou, na revista "Desenvolvimento literário para o inválido", algo que poderia lembrar uma oposição: mas sua oposição consistia em notas leves dos erros das revistas, por vezes uma ironia bem-sucedida, demonstrada de uma forma descontínua, em poucas palavras, por vezes com chistes, com muito sentido para poucos literatos, mas imperceptível para os não-iniciados. As críticas bem fundamentadas e minuciosas, que poderiam definir qualquer direção à nova revista, não foram publicadas por ele em nenhum lugar. O "Telescópio", em colaboração com o "Rumor", atuou contra a "Biblioteca para a leitura", mas agiu de forma débil, fraca, sem consistência, paciência e o necessário sangue frio. Nas matérias críticas isso era demonstrado apenas com a indignação para com os novos abastados, deboches sobre o baronato do senhor Senkóvski, e fazia alguns comentários dignos com relação a suas imitações de escritores franceses, mas não viu propósito em toda essa clareza. No "Rumor" repetiu-se a mesma alusão a Brambeus, frequentemente com relação à análise de compêndios completamente

24 Revista que trazia ilustrações sobre moda e notícias. Começou a ser editada em 1831 e, em 1832, foi anexada à revista “Telescópio”. Seu principal nome era V. G. Belínski. (N. do T.) 
estranhos. Além do mais, o "Telescópio" muito se prejudicou com análise de livretos ultrapassados, com a incorreção da edição e com suas matérias críticas que, por vezes, pareciam ser do avesso.

É óbvio que as vontades e os meios destas revistas eram deveras débeis em comparação com a "Biblioteca para leitura", que se encontrava entre eles tal como um elefante entre quadrúpedes. Tal luta era consideravelmente injusta e eles, ao que parece, não levaram em consideração que a "Biblioteca para leitura" mantinha próximo de cinco mil assinantes, que a opinião da "Biblioteca para leitura" se espalhava por todas as camadas da sociedade, nas quais sequer se havia ouvido falar sobre a existência do "Telescópio" e do "Desenvolvimento da literatura", que as posições e compilados, dispostos na "Biblioteca", eram elogiados pelos próprios editores da "Biblioteca", escondidos sob diferentes alcunhas, e elogiados com entusiasmo, sempre exercendo influência em grande parte do público, pois exatamente tudo aquilo que soa engraçado para os leitores iniciados é levado em consideração pelos mais limitados e ingênuos, e estes sem dúvida, pode-se supor, seriam maioria entre os leitores da "Biblioteca". Além disso, a maior parte dos assinantes eram pessoas jovens, que não conheciam revistas, portanto tomavam tudo como verdade absoluta. E, por fim, que a "Biblioteca para leitura" garantia para si um reforço de 4 mil exemplares da "Abelha do Norte".

\section{О Авижении журнальной митературы в 1834 и 1835 году}

Журнальная митература, эта живая, свежая, говорливая, чуткая Аитература, так же необходима в области наук и художеств, как пути сообщения Аля государства, как ярмарки и биржи Аля купечества и торговАи. Она ворочает вкусом толпы, обращает и пускает в ход всё выходящее наружу в книжном мире, и которое без того было бы в обоих смыслах мертвым капиталом. Она - быстрый, своенравный размен всеобщих мнений, живой разговор всего тиснимого типографскими станками; ее голос есть верный преАставитель мнений целой эпохи и века, мнений, без нее бы исчезнувших безгласно. Она волею и неволею захватывает и увлекает в свою область Аевять десятых всего, что делается принадлежностию митературы. Сколько есть АюАей, которые судят, говорят и толкуют потому, что все сужАения поднесены им почти готовые, и которые сами от себя вовсе не толковали бы, не судили, не говорили. Итак, журнальная Аитература во всяком случае имеет право требовать самого пристального внимания.

Может быть, Аавно у нас не было так резко заметно отсутствия журнальной деятельности и живого современного Авижения, как в послеАние 
Ава года. Бесцветность была выражением большей части повременных изданий. Многие старые журналы прекратились, Аругие тянулись меАленно и вяло; новых, кроме Библиотеки Аля чтения и впослеАствии Московского наблюдателя, не показацось, между тем, как именно в это время была заметна всеобщая потребность умственной пищи, и значительно возросло число читающих. Как ни бедна эта эпоха, но она, такое же имеет право на наше внимание, как и та, которая бы кипела движением, ибо также принаАлежит истории нашей словесности. Читатели имели полное право жаловаться на скудость, и постный вид наших журналов: Телеграф давно потерял тот резкий тон, который давало ему воинственное его положение, в отношении журналов петербургских. Телескоп наполнялся статьями, в которых не было ничего свежего, животрепещущего. В это время книгопродавец Смирдин, Аавно уже известный своею деятеАьностию и добросовестностию, который оАин Только, к стыАу прочих недаАьнозорких своих товарищей, показал предприимчивость и своими оборотами АаА Авижение книжной торговле, книгопродавец Смирдин решился издавать журнал обширный, энциклопедической, завоевать всех митераторов, сколько ни есть их в России, и заставить их участвовать в своем предприятии. В программе были выстав ены имена почти всех наших писателей. Профессор арабской словесности г-н Сенковский взялся быть распоряАителем журнала; к нему был присоединен редактором г-н Греч, известный уже постоянным изАанием двух журналов: Северной пчелы и Сына отечества. Не знаем, сами ми они взялись за сие Аело или упрошены были г-ном Смирдиным; но в том и Аругом случае книгопродавец, по общему мнению, поступиц несколько неосмотрительно.

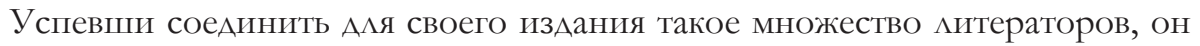
Аолжен был предоставить их суду избрание редактора.

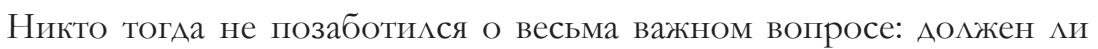
журнал иметь один определенный тон, одно уполномоченное мнение, или быть склаАочным местом всех мнений и толков. Журнал на сей счет отозвался глухо, обыкновенным объявлением, что критика будет самая благонамеренная и беспристрастная, чуждая всякой мичности и неприличности, - обещание, которое дает всякой журналист. С выходом первой книжки публика ясно увидела, что в журнале господствует тон, мнения и мысли одного, что имена писателей, которых блестящая шеренга наполнила полстраницы заглавного мистка, взята была только напрокат, Аля привлечения большего чис $а$ подписчиков.

Книгопродавец Смирдин исполнил с своей стороны всё, чего публика вправе была от него требовать. Ту же самую честность, которая 
всегда отАичала его, показал он и в издании журнаца. Журнац выходиц с необыкновенною исправностию: подписчики вместе с первым числом каждого месяца встречали толстую книгу, какой у нас в прежнее время ни одна типография не могла бы поставить в Ава месяца. Вместо обещанного числа осьмнадцати Аистов в месяц, выходило иногда вдвое более. Теперь

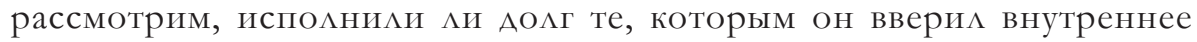
распоряжение журнала. - ГАавным деятелем и Авижущею пружиною всего журнала был г-н Сенковский. Имя г-на Греча выстав еено было только Аля формы, по крайней мере никакого действия не было заметно с его стороны. Г-н Греч давно уже слелался почетным и необходимым редактором всякого предпринимаемого периодического издания: так обыкновенно почтенного пожилого человека приглашают в посаженые отцы на все свадьбы. Но какая цель была редакции этого журнала, какую залачу прелположила она решить? ЗАесь поневоле должны мы задуматься, что, без сомнения, сделает и читатель. В программе ничего не сказац г-н Сенковский о том, какой начертац Аля себя путь, какую выбрал себе цель; все увилели только, что он взошел незаметно в первый номер и в конце его развернулся как полный хозяин.

Впрочем нельзя жаловаться и на это: положим, Аля журналиста необходим резкий тон и некоторая даже дерзость (чего однако ж мы не одобряем, хотя нам известно, что с подобными качествами журналисты всегда выигрывают в мнении толпы), но на что преимущественно было обращено внимание сего хозяина, какая мысль его пересиливала все прочие, к чему

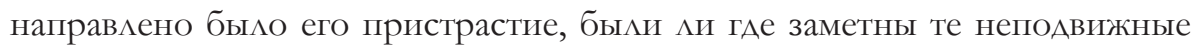
правила, без коих человек делается бесхарактерным, которые Аают ему оригинальность и определяют его физиогномию?

Прочитавши всё, помещенное им в этом журнале, следуя за всеми словами, сказанными им, невольно остановимся в изумлении: что это такое? что заставляло писать этого человека? Мы виАим человека, который берет Аеньги вовсе не Ааром, который трудится до поту мица, не только заботится о своих статьях, но Ааже переправляет чужие, одним словом, явцяется неутомимым. Аля чего же вся эта деятельность? Последуем за распорядителем во всех родах его сочинений и скажем несколько слов о главных качествах его статей. Это во всех отношениях необходимо.

Г-н Сенковский является в журнале своем как критик, как повествователь, как ученый, как сатирик, как глашатай новостей и проч. и проч., яв яется в виде Брамбеуса, Морозова, Тютюнджу Оглу, А. Белкина, наконец в собственном виде. Как ученый, г-н Сенковский поместил Аовольно большую статью о сагах, статью, исполненную ипотез, не собственных, 
но схваченных наудачу из разных бегло прочитанных книг, ипотез, вовсе не принаАлежащих русской истории. Эти саги, которые проницательный Шлецер, не имеющий Аоныне равного по строгому и глубокому критическому взгляду, признац за басни, недостойные никакого внимания, эти саги он ставит краеугольным камнем русской истории и не приводит ни одного Аоказательства, поверенного критикою: он вовсе не определил их истинного и единственного достоинства. Саги суть поэтическое создание народа, игравшего великую в истории роль. Эта статья, испещренная риторическими фигурами, понравилась добрым, но ограниченным Аюдям, а г-н Булгарин даже написал рецензию, в которой поставил г-на Сенковского выше Шлецера, Гумбольта и всех когда-либо существовавших ученых. Аругое весьма важное притязание г. Сенковского и настоящий конек его есть Восток. ЗАесь он всегАа возвышац голос, и как только выходило какоенибудь сочинение о Востоке или упоминалось где-нибудь о Востоке, хотя бы даже это было в стихотворении, он гневался и утверждац, что автор не может судить и не Аолжен судить о Востоке, что он не знает Востока. Слово, сказанное с сердцем, очень извинительно в человеке, влюбленном в свой предмет и который между тем видит, как мало понимают его Аругие; но этот человек уже должен по крайней мере утвердить за собою авторитет. Г-ну Сенковскому точно следовало бы издать что-нибудь о Востоке. Человеку,

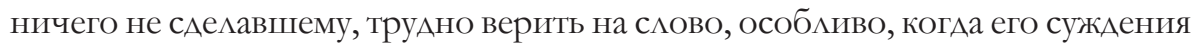
так легковесны и проникнуты духом нетерпимости; а из некоторых его отрывков о Востоке видны те же самые недостатки, которые он беспрестанно порицает у Аругих. Ничего нового не сказац он в них о Востоке, ни одной яркой черты, сильной мысли, гениального предположения! Нельзя отвергать, чтобы г-н Сенковский не имел сведений; напротив, очень виАно, что он много читац, но у него нигде не заметно этой Авижущей, господствующей силы, которая направ яла бы его к какой-нибудь цели. Все эти сведения находятся у него в каком-то брожении, Аруг Аругу противоречат, между собой не уживаются. Рассмотрим его мнения, относящиеся собственно к текущей изящной Аитературе. В критике г-н Сенковский показац отсутствие всякого мнения, так что ни один из читателей не может сказать наверное, что̀ более нравицось рецензенту и заняло его Аушу, что̀ пришлось по его чувствам: в его рецензиях нет ни положительного, ни отрицательного вкуса, - вовсе никакого. То, что ему нравится сегодня, завтра делается предметом его насмешек. Он первый поставиц г-на Кукольника наряду с Гёте, и сам же объявиц, что это слелано им потому только, что так ему вздумалось. Стало быть, у него рецензия не есть Аело убеждения и чувства, а просто следствие 
расположения духа и обстоятельств. Вальтер Скотт, этот великий гений, коего бессмертные созАания объемлют жизнь с такою полнотою, Вальтер Скотт назван шарлатаном. И это читала Россия, это говорицось цюАям уже образованным, уже читавшим Вальтер Скотта. Можно быть уверену, что г-н Сенковский сказал это без всякого намерения, из одной опрометчивости; потому что он никогАа не заботится о том, что говорит, и в следующей статье уже не помнит вовсе написанного в предыдущей.

В разборах и критиках г-н Сенковский тоже никогАа не говориц о внутреннем характере разбираемого сочинения, не определял верными и точными чертами его достоинства. Критика его была или безусловная похва^а, в которой рецензент от всей Ауши тешился собственными фразами, или хула, в которой отзывалось какое-то странное ожесточение. Она состояла в мелочах, ограничивалась выпискою двух-трех фраз и насмешкою. Ничего не было сказано о том, что предполагал себе целью автор разбираемого сочинения, как оное выполнил и, если не выполниц, как Аолжен был выполнить. Больше всего г-н Сенковский занимался разбором разного Аитературного сора, множеством всякого рода пустых книг; наА ними шутиц, труниц и показываА то остроумие, которое так нравится некоторым читателям. Наконец Ааже завязал целое дело о двух местоимениях: сей и оный, которые показались ему, неизвестно почему, неуместными в русском слоге. Об этих местоимениях писаны им были целые трактаты, и статьи его, рассужАавшие о каком бы то ни было предмете, всегда оканчивались тем, что местоимения сей и оный совершенно неприличны. Это напомнило старый процесс Тредьяковского за букву ижицу и десятеричное i, который впоследствии еще не так Аавно поддерживал один профессор. Книга, в которой г-н Сенковекий встречал эти Аве частицы, была торжественно признаваема написанною Аурным слогом.

Его собственные сочинения, повести и тому подобное, явАялись под фирмою Брамбеуса. Эти повести и статьи вроде повестей, своим близким, неумеренным подражанием нынешним писателям французским, произвели всеобщее изумление, потому что г. Сенковский охужАал гласно всю текущую французскую Аитературу. Непостижимо, как в этом случае он имел так мало сметАивости и до такой степени считал простоватыми своих читателей. Неизвестно тоже, почему называц он некоторые статьи свои фантастическими. Отсутствие всякой истины, естественности и вероятности еще нельзя считать фантастическим. Фантастические сочинения Барона Брамбеуса напоминают книги, каких некогАа было очень много, как-то: “Не ^юбо - не слушай, а мгать не мешай”, и тому подобные. Та же безотчетность 
и еще менее устремления к доказательству какой-нибудь мысли. Опытные читатели заметили в них чрезвычайно много похищений, слеланных наскоро, на всем бегу: автор мацо заботился о их связи. То, что в оригиналах имело смысл, то в копии было без всякого значения.

Таковы были труды и действия распорядитемя Библиотеки Аля чтения. Мы почли нужным упомянуть о них несколько обстоятельнее потому, что он один законодательствовац в Библиотеке Аля чтения и что мнения его разносились чрезвычайно быстро, вместе с четырьмя тысячами экземпляров журнала, по всему мицу России.

Невозможно, чтобы журнал, издаваемый при средствах, доставленных книгопродавцем Смирдиным, был плох. Он уже выигрывал тем, что издавался в большом объеме, толстыми книгами. Это Аля подписчиков была приятная новость, особливо Аля жителей наших городов и сельских помещиков. В Библиотеке находились переводы иногда Аюбопытных статей из иностранных журналов, в отделе стихотворном попаАались имена светиц русского Парнаса. Но постоянно цучшим отАелением ее была смесь, вмещавшая в себе очень много разнообразных свежих новостей, отделение живое, чисто журнальное. Изящная проза, оригинальная и переводная, повести и прочее, - оказывала очень мацо вкуса и выбора. В Библиотеке Аля чтения случилось еще одно, дотоле неслыханное на Руси явление. Распорядитель ее стал переправ яять и переделывать все почти статьи, в ней печатаемые, и мюбопытно то, что он объяв яя об этом сам Аовольно смело и откровенно. 'У нас, - говорит он, - в Библиотеке Аля чтения, не так, как в Аругих журналах: мы никакой повести не оставцяем в прежнем виАе, всякую переделываем: иногда составляем из двух одну, иногда из трех, и статья значительно улучшается нашими переделками". Такой странной опеки до сих пор на Руси еще не бывало.

Многие писатели начали опасаться, чтобы публика не приняла статей, часто помещаемых без подписи или под вымышленными именами, за их собственные, и потому начаци отказываться от участия в издании сего журнала. Число сотрудников так умалилось, что на Аругой год изАатели уже не выставили Алинного списка имен и упомянули глухо, что участвуют мучшие митераторы, не означая какие. Журнац хотя не изменился в величине и плане, но статьи заметно начали быть хуже; видно было менее старания. Библиотеку уже менее читали в столицах, но всё так же много в провинциях, и мнения ее так же обращались быстро. Обратимся к Аругим журналам.

Северная пчела заключала в себе официальные известия и в этом отношении выполнила свое дело. Она помещала известия политические, 


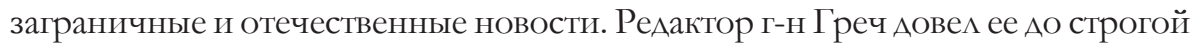

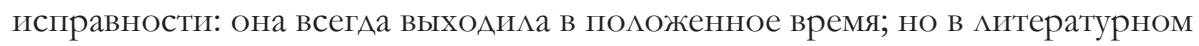
смысле она не имела никакого определенного тона и не выказывала никакой симьной руки, Авигавшей ее мнения. Она была какая-то корзина, в которую сбрасывац всякой всё, что ему хотелось. Разборы книг, всегда почти благоскцонные, писались приятелями, а иногда самими авторами. В Северной пчеле пробовали остроту пера разные незнакомцы, скрывавшиеся под разными буквами, без сомнения, АюАи молодые, потому что в статьях выказывалось довольно удацьства. Они нападали разве уже на самого беззащитного и круглого сироту. Насчет неопрятных изданий явАялись остроумные колкости, несколько похожие одна на Аругую. Сущность рецензий состояла в том, чтобы расхвалить книгу и при конце сложить с себя весь грех такою оговоркою: “Впрочем желательно, чтобы почтенный автор исправил небольшие погрешности относительно языка и слога", или: “Хорошая книга требует хорошего издания”, и тому подобное, за что автор разбираемой книги иногда обижался и жалова^ся на пристрастие рецензента. Книги часто были разбираемы теми же самыми рецензентами, которые писали известия о новых табачных фабриках, открывавшихся в столице, о помаде и проч.; сии известия иногда довольно остроумны и в шутках своих показывали Аовких, и хорошо воспитанных Аюдей, без сомнения, имевших основательные причины быть довольными фабрикантами. Впрочем от Сев<ерной> пчелы больше требовать было нечего: она была всегда исправная ежедневная афиша, ее Аелом было пригласить публику, а судить она предостав яя а самой пубоиике.

Журнац, носивший название Сына отечества и Северного архива, был почти невиАимкою во всё время. О нем никто не говорил, на него никто не ссылался, несмотря на то, что он выходиц исправно еженедельно и что печатал такую огромную программу на своей обвертке, какую вряА $\Lambda и$ где можно было встретить. В Сыне отечества (говорила программа) будет археология, медицина, правоведение, статистика, русская история, всеобщая история, русская словесность, иностранная словесность, наконец просто словесность, география, этнография, историческая галиерея и прочее. Иной ахнет, прочитавши такую ужасную программу, и подумает, что это огромнейшее энциклопедическое издание, когда-либо существовавшее на свете. Ничуть не бывало: выходица худенькая, тоненькая книжечка в три миста, начинавшаяся статьею о каких-нибудь болезнях, которой не читали Ааже медики. Критическая статья, а тем еще более живая и современная, не была в нем постоянною. Новости политические были те же сухие факты, 
взятые из Северной пчелы, следственно уже всем известные. Помещаемые какие-то оригинальные повести были довольно странны, чрезвычайно коротенькие и совершенно бесцветны. Если попадалось что-нибудь достойное замечания, то оно оставацось незаметным. Имена редакторов

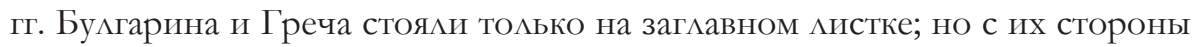
решительно не было видно никакого участия. ОАнако ж журнал существовац, стало быть, читатели и подписчики были. Эти читатели и подписчики были почтенные и пожилые АюАи, живущие в провинциях, которым что-нибудь почитать так же необходимо, как заснуть часик после обеда или выбриться Ава раза в неделю.

Издавалась еще в Петербурге в продолжение всего этого времени газета чисто Аитературная, освобожденная от всяких вторжений наук и важных сведений, не политическая, не статистическая, не энциклопедическая, мюбительница старого, но при всем том имевшая особенный характер. Название этой газеты: Аитературные прибавления к Инвалилу. В ней помещались мегонькие повести: беседы деревенских помещиков о Аитературе, беседы, часто довольно обыкновенные, но иногда местами проникнутые колкостями, близкими к истине: читатель к изумлению своему вилел, что помещики к концу статьи Аелались совершенными Аитераторами, принимали к сердцу текущую митературу и приправ яли свои мнения еАкою насмешкою. Этот журнац всегда оказывац оппозицию противу всякого счастАивого наезАника, хотя его вся тактика часто состояла только в том, что он выписывац одно какое-нибудь место, Аоказывающее журнальную опрометчивость, и присовокуплял от себя довольно зцое замечание не Алиннее строчки с восклицательным знаком. Г-н Воейков был чрезвычайно Аеятельный Аовец и, как рыбак, силел с удой на берегу, не теряя терпения, хотя на его уду попадалась большею частию мелкая рыба, а большая обрывалась. В редакторе была заметна чисто митературная жизнь, и он с неохлажденным вниманием не сводиц глаз с журнального поля. Я не знаю, много ми было читате ей его газеты, но она очень стоица того, чтобы иногда в нее заглянуть.

В Москве издавался один только Телескоп, с небольшими Аистками прибавления, под именем Молвы; журнац, вначаце отозвавшийся живостью, но вскоре простывший, наполнявшийся статьями без всякого разбора, Аишенный всякого Аитературного Авижения. ВиАно было, что издатели не прилагали о нем никакого старания и вылава^и книжки как-нибудь.

Монополия, захваченная Библиотекою Аля чтения, не могла не залеть за живое Аругих журналов. Но Северная пчела была издаваема тем же самым г-ном Гречем, которого имя некоторое время стояло на заглавном 
мистке в Библиотеке как главного ее редактора, хотя это звание, как мы уже вилели, было только почетное, и потому очень естественно, что Северная пчела должна была хвалить всё, помещаемое в Библиотеке, и настоящего ее Авижителя, явАявшегося под множеством разных имен, называть русским Гумбольтом. Но и без того она вряА Аи бы могла явиться сильною

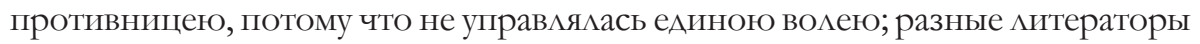
заглядывали туда только по своей надобности. Сын отечества Аолжен был повторять слова Пчелы. Итак, всего только два журнала могли восстать против его мнений. Г-н Воейков показац в Аитературных прибав ениях что-то похожее на оппозицию; но оппозиция его состоя Аа в Аегких заметках журнальных промахов и иногда удачной остроте, выраженных отрывисто, в немногих словах, с насмешкою, очень понятною Аля немногих Аитераторов, но незаметною Аля непосвященных. Нигде не поместил он обстоятельной и основательной критики, которая определила бы сколько-нибудь направление нового журнала. Телескоп в соединении с Молвою действовац против Библиотеки Аля чтения, но Аействовац слабо, без постоянства, терпения и необходимого хладнокровия. В статьях критических он был часто исполнен негодования против нового счастАивца, шутил наА баронством г-на Сенковского, слелац несколько справедливых замечаний относительно его странного подражания французским писателям, но не вилел дела во всей ясности. В Молве повторялись те же намеки на Брамбеуса часто по поводу разбора совершенно постороннего сочинения. Кроме того, Телескоп много вредил себе опаздыванием книжек, неаккуратностию издания, и критические статьи его чрез то еще менее были в обороте.

Очевилно, что силы и средства этих журналов были слишком слабы в отношении к Библиотеке Аля чтения, которая была межАу ними, как слон межАу мелкими четвероногими. Их бой бы слишком неравен, и они, кажется, не приняли в соображение, что Библиотека Аля чтения имела около пяти тысяч подписчиков, что мнения Библиотеки Аля чтения разносились в таких слоях общества, где даже не слышали, существуют ми Телескоп и Аитературные прибав ения, что мнения и сочинения, помещаемые в Библиотеке Аля чтения, были расхвалены изАателями той же Библиотеки Аля чтения, скрывавшимися под разными именами, расхвалены с энтузиазмом, всегда имеющим вАияние на большую часть публики; ибо то, что смешно А^я читателей просвещенных, тому верят со всем простодушием читатели ограниченные, каких по количеству подписчиков можно предполагать более межАу читате ями Библиотеки, и к тому же большая часть подписчиков были Аюди новые, дотоле не знавшие журналов, следственно принимавшие всё 
за чистую истину; что наконец Библиотека Аля чтения имела сильное Аля себя подкрепление в 4000 экземплярах Северной пчемы.

Ропот на такую неслыханную монополию слелался силен. В Москве наконец несколько митераторов решились издавать какой-нибудь свой

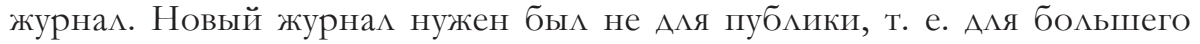
числа читателей, но собственно Аля Аитераторов, разАично притесняемых Библиотекою. Он был нужен: 1) Аля тех, которые желали иметь приют Аля своих мнений, ибо Библиотека Аля чтения не принимала никаких критических статей, если не были они по вкусу главного распорядителя; 2) Аля тех, которые вилели с изумлением, как на их собственные сочинения наложена была рука распорядителя, ибо г-н Сенковский начал уже переправ яять, безо всякого разбора Аиц, все статьи, отдаваемые в Библиотеку.

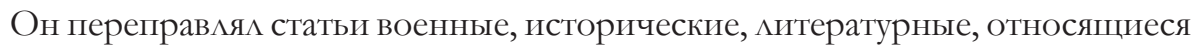
к политической экономии и проч., и всё это Аелац без всякого Аурного намерения, Ааже без всякого отчета, не руководствуясь никаким чувством налобности или приличия. Он даже приделал свой конец к комедии Фонвизина, не рассмотревши, что она и без того была с концом.

Всё это было очень АосаАно Аля писателей, решите ьно не имевших места, куда бы могли подать жалобу свету и читателям.

Но уже один слух о новом журнале возбудиц негодование Библиотеки А^я чтения и подвинул ее к неожиданному поступку: она уверяла своих

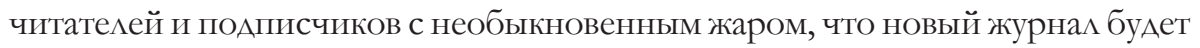
бранчивый и неблагонамеренный. Статья, помещенная по этому же случаю в Северной пчеле, казалось, была писана человеком, в отчаянии предвилевшим свою конечную погибель. В ней уведомляли публику, что новый журнал хотел уронить Библиотеку Аля чтения, потому только, что издатели оного объявили, что будут выпускать таковое же число мистов, как и Библиотека А^я чтения. Поступок чрезвычайно неосмотрительный! В подобном Аеле необходимо скрыть свои мелкие чувства искусно и потом, выжАав удобный случай, нанесть обдуманный удар. Если я издаю журнац, зачем же не издавать его и Аругому? И как могу гневаться, если Аругой скажет, что он будет брать меня в образец? Не Аолжен ми я, напротив, его благодарить? Не показывает Аи он тем степень уважения, мною заслуженного в публике? Чем больше

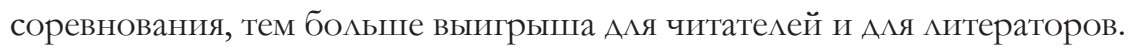

Но рассмотрим, в какой степени Московский наблюдатель выполниц ожилания публики, жаАной до новизны, ожиАание читателей образованных, ожилание митераторов и опасение Библиотеки Аля чтения. 
Новый журнац, несмотря на ревностное старание привести себя во всеобщую известность, не имел среАств огласить во все углы России о своем появлении, потому что единственные глашатаи вестей были его противники - Северная пчела и Библиотека Аля чтения, которые, конечно, не поместили бы благоприятных о нем объявлений. Он начался довольно позАно, не с новым годом, следственно не в то время, когда обыкновенно начинаются подписки, наконец он пренебрег быстрым выходом книжек и срочною их поставкою. Но важнейшие причины неуспеха заключались в характере самого журнала. По первым вышедшим книжкам уже можно было видеть, что преАположение журнала было слеАствием одного горячего мгновения. В Московском наблюдателе тоже не было видно никакой сильной пружины, которая управляла бы ходом всего журнала. Редактор его вилен был только на заглавном Аистке. Имя его было почти неизвестно. Он написал доселе несколько сочинений статистических, имеющих много достоинства, но которых публика чисто Аитературная не знала вовсе. Аитературные мнения его были неизвестны. В этом состояла большая ошибка издателей Московского наблюдателя. Они позабыли, что редактор всегда Аолжен быть видным Аицом. На нем, на оригинальности его мнений, на живости его слога, на общепонятности и общезанимательности языка его, на постоянной свежей деятельности его, основывается весь кредит журнала. Но г-н АнАросов явился в Московском наблюдателе вовсе незаметным Аицом. Если желание издателей было постановить только почетного редактора, как вошло в обычай у нас на Аенивой Руси, то в таком случае они должны были труды редакции разложить на себя; но они оставили всю ответственность на редакторе, и Московский наблюдатель стал похож на те ученые общества, гАе члены ничего не Аелают и даже не бывают в присутствии, межАу тем, как президент является каждый Аень, садится в свои кресла и велит записывать протокол своего уединенного заседания. В журнале было несколько очень хороших статей, его украсили стихи Языкова и Баратынского - эти перлы русской поэзии, но при всем том в журнале не было заметно никакой современной живости, никакого хлопотливого Авижения; не было в нем разнообразия, необходимого Аля издания периодического. Замечательные статьи, поступавшие в этот журнац, были похожи на оазисы, зеленеющие посреди целого моря песчаных степей. Притом издатели, как кажется, мало имели сведения о том, что нравится и что не нравится публике. Статьи часто хорошие Аелались скучными, потому только, что они тянулись из оАного нумера в Аругой с несносною подписью: “продолжение впредь”. Вот каков был журнал, Аолженствовавший бороться с Библиотекой Аля чтения. 
Наблюдатель начался оппозиционною статьею г. Шевырева о торговле, зародившейся в нашей митературе. В ней автор нападает на торговлю в ученом мире, на всеобщее стремление составить себе доход из Аитературных занятий. Первая ошибка была здесь та, что автор статьи обратил внимание не на главный предмет. Во-вторых: он гремел против пишущих за деньги, но не разрушил никакого мнения в публике касательно внутренней ценности товара. Статья сия была понятна одним Аитераторам, нанесла досаАу Библиотеке Аля чтения, но ничего не дала знать пубиике, не понимавшей Ааже, в чем состояло Аело. Притом сии нападения были несправеАливы, потому что устремлялись на непреложный закон всякого Аействия. Аитература Аолжна была обратиться в торговАю, потому что читатели и потребность чтения увеличилась. Естественное дело, что при этом случае всегла больше выигрывают Аюди предприимчивые, без большого таланта, ибо во всякой торговле, гАе покупщики еще простоваты, выигрывают больше купцы оборотливые и пронырливые. Аолжно показать, в чем состоит обман, а не пересчитывать их барыши. Что литератор купил себе Аоходный Аом или пару мошадей, это еще не беАа; дурно то, что часть беАного народа купила худой товар и еще хвалится своею покупкою. Аолжно было обратить внимание г-ну Шевыреву на бедных покупщиков, а не на продавцов. Продавцы обыкновенно бывают Аюди наездные: сегодня здесь, а завтра бог знает где. При этом случае слелан был несправедливый упрек книгопродавцу Смирдину, который вовсе не виноват, который за предприимчивость и честную Аеятельность заслуживает одну только благодарность. Нет спора, что он Аал, может быть, много воли Аюдям, которым приличнее было заниматься просто торговлею, а не митературою. Талант не искателен, но корыстолюбие искательно. На это так же смешно жаловаться, как было бы странно жаловаться на правительство, встретивши неАальновидного чиновника. Аля таланта есть потомство, этот неподкупный ювелир, который оправляет одни чистые брилАианты. Г-н Шевырев показал в статье своей благородный порыв негодования на прозаическое, униженное направление митературы, но на большинство публики эта статья решительно не сАелала никакого впечатления. Библиотека отвечала коротко в духе обыкновенной своей тактики: обратившись к зрителям, т. е. к подписчикам, она говорила: “Вот какое неблагородство духа показал г-н Шевырев, неприличие и неимение высоких чувств, упрекая нас в том, что мы трудимся для денег, тогда как” и проч... Это обыкновенная политика петербургских журналов и газет. Как только кто-нибудь сделает им упрек в корыстолюбии и в бездействии, они всегда жалуются публике на неприличие выражений и неблагородство 
Ауха своих противников, говорят, что статья эта писана с целию только подАеть публику и забрать от читателей деньги, что они почитают с своей стороны священным Аолгом предуведомить публику.

Итак, выходка Московского наблюдателя скользнула по Библиотеке А^я чтения, как пуля по толстой коже носорога, от которой Ааже не чихнуло тучное четвероногое. Выславши эту пулю, Московский наблюдатель замолчац, - доказательство, что он не начертац Аля себя облуманного плана Аействий и что решительно не знал, как и с чего начать. Аолжно было или не начинать вовсе, или если начать, то уже не отставать. Только постоянным действием мог Наблюдатель дать себе ход и сделать имя свое известным публике, как слелац его известным Телеграф, Аействуя таким же образом и почти при таких же обстоятельствах. Наблюдатель выпустил вслеА за тем несколько нумеров, но ни в одном из них не сказал ничего в защиту и подкрепление своих мнений. Чрез несколько нумеров показалась наконец статья, посвященная Брамбеусу, по поводу одной давно напечатанной в Библиотеке статьи, под именем: “Брамбеус и юная словесность”, в которой Брамбеус назва^ сам себя законодателем какой-то новой школы и вводителем новой эпохи в русской Аитературе.

Это в самом деле было чрезвычайно странно. Случалось, что митераторы иногда похваливали самих себя, или под именем друзей своих, или Ааже сами от себя, но всё же с некоторою застенчивостию, и после сами старались всё это как-нибудь загресть собственными руками, чувствуя, что несколько провиницись. Но никогда еще автор не хвациц себя так свободно и непринужденно, как барон Брамбеус. Эта оригинальная статья слишком была ярка, чтобы не быть замеченною. Ею занялся и Телескоп и потруниц наА нею Аовольно забавно, только вскользь; с обыкновенною сметливостию о ней намекнул и г-н Воейков; она возродила статью и в Московском наблюдателе. Цель этой статьи была доказать, откуда барон Брамбеус почерпнул талант свой и знаменитость? какими творениями чужих хозяев пользовался, как своим? Аругими словами: из каких иоскутов барон Брамбеус сшил себе халат? Несколько безгласных книжек, выходивших вслед за тем, совершенно погрузили Московского наблюдателя в забвение. Ааже самая Библиотека Аля чтения перестала наконец упоминать о нем, как о бессильном противнике; продолжала шутить наА важным и неважным и говорить всё то, что первое попаАацось под перо ее.

Вот каковы были действия наших журналов. Изложив их, рассмотрим теперь, что сделали они в эти два года такого, которое должно вписаться в историю нашей митературы, оставить в ней свою оригинацьную черту; 
какие мнения, какие толки они утверАили, что определили и какой мысли Аали право гражданства.

Аиинная программа, сулящая статистику, медицину, митературу, ничего не значит. Извещение о том, что критика будет благонамеренная, чуждая мичностей и партий, тоже не показывает цели. Она Аолжна быть необходимым условием всякого журнала. Ааже множество помещенных в журнале статей ничего не значит, ес и журнац не имеет своего мнения и не оказывается в нем направ ение, хотя даже одностороннее, к какой-нибудь цели. Телеграф издавался, кажется, с тем, чтобы испровергнуть обветшалые, заматерелые, почти машинальные мысли тогдашних наших старожилов, классиков; Московский вестник, один из цучших журнацов, несмотря на то, что в нем немного было современного Авижения, издавался с тем, чтобы познакомить публику с замечательнейшими созданиями Европы, раздвинуть круг нашей митературы, Аоставить нам свежие идеи о писате ях всех времен и народов. ЗАесь не место говорить, в какой степени оба сии журнала выполнили цель свою; по крайней мере стремление к ней было чувствуемо в них читателями. Но рассмотрите внимательно издававшиеся в последние Ава года журналы; уловите главную нить кажАого из них: сей-то нити и не сыщете. Развернувши их, будете поражены мелкостью предметов, вызвавших толки их. Подумаете, что решительно ни одного важного события не произошло в Аитературном мире. А межАу тем:

1) Умер знаменитый шотландец, великий дееписатель сердца, природы и жизни; полнейший, обширнейший гений XIX века.

2) В митературе всей Европы распространился беспокойный, волнующийся вкус. ЯвАялись опрометчивые, бессвязные, младенческие творения, но часто восторженные, пламенные - следствие политических волнений той страны, где рождались. Странная, мятежная, как комета, неорганизованная, как она, эта $и$ итература волновала Европу, быстро облете а все углы читающего мира. Пусть эти яв ения будут всемирно-европейские, хотя они отражались и в России; рассмотрим митературные события чисто русские:

3) Распространилось в большой степени чтение романов, холодных, скучных повестей, и оказалось очень явно всеобщее равнодушие к поэзии.

4) Вышли новыми изданиями Аержавин, Карамзин, гласно требовавшие своего определения и настоящей верной оценки так, как и все прочие

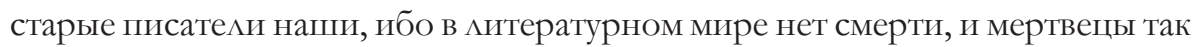
же вмешиваются в дела наши и действуют вместе с нами, как и живые. Они 
требовали возвращения того, что Аействительно им следует; они требовали уничтожения неправого обвинения, неправого определения, бессмысленно повторенного в продолжение нескольких мет и повторяемого доныне.

Но сказали ми журналы наши, руководимые строгим размышлением, что такое был Вальтер Скотт, в чем состояло вАияние его, что такое французская современная Аитература, отчего, откуда она произошла, что было поводом неправильного укцонения вкуса и в чем состоял ее характер? Отчего поэзия заменилась прозаическими сочинениями? На какой степени образования стоит русская публика и что такое русская публика? В чем состоит оригинальность и свойство наших писателей?

Напрасно в этом отношении читатель станет искать в них новых мыслей или каких-нибудь следов глубокого, Аобросовестного изучения. Вальтер Скотта у нас только побранили. Французскую митературу одни приняли с Аетским энтузиазмом, утвержАали, что модные писатеАи проникнули тайны сердца человеческого, Аотоле сокровенные Аля Сервантеса, Аля Шекспира... Аругие безотчетно поносили ее, а межАу тем сами писали во вкусе той же школы еще с большими несообразностями. Вопросом: отчего у нас в большом ходу водяные романы и повести? вовсе не занялись, а вместо того вдобавок напустили и своих еще собственных. О нашей публике сказали только, что она почтенная публика и что АОлжна подписываться на все журналы и разные издания, ибо их может читать и отец семейства, и купец, и воин, и митератор; о Аержавине, Карамзине и Крылове ничего не сказали или сказали то, что говорит уездный учитель своему ученику, и отделались пошлыми фразами.

О чем же говорили наши журналисты? Они говорили о ближайших и

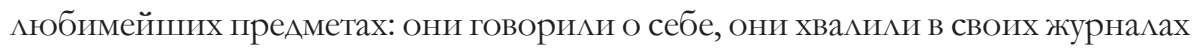
собственные свои сочинения; они решительно были заняты только собою; на всё Аругое они обращали какое-то холодное, бесстрастное внимание. Великое и замечательное было как будто невидимо. Их равнодушная критика обращена была на те предметы, которые почти не заслуживали внимания.

В чем же состоял главный характер этой критики? В ней очень явственно было заметно:

1) Пренебрежение к собственному мнению. Почти никогда не было заметно, чтобы критик считал свое дело важным и принимался за него с благоговением и предварительным размышлением, чтобы, водя пером своим, думал о небольшом числе возвышенно-образованных современников, перед которыми он должен дать ответ в каждом своем слове. Журнальная 
критика по большой части была каким-то гаэрством. Как хвалили книгу покровительствуемого автора? Не говорили просто, что такая-то книга хороша или Аостойна внимания в таком-то и таком-то отношении, совсем нет. «Это книга, - говорили рецензенты, - удивительная, необыкновенная, неслыханная, гениальная, первая на Руси, продается по пятнадцати рублей; автор выше Вальтер Скотта, Гумбольта, Гёте, Байрона. Возьмите, переплетите и поставьте в библиотеку вашу; также и второе издание купите и поставьте в библиотеку: хорошего не мешает иметь и по два экземпляра».

Большая часть книг была расхвалена без всякого разбора и совершенно безотчетно. Если счесть все те, которые попали в первоклассные, то иной

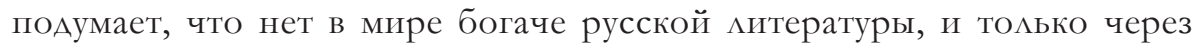
несколько времени противоположные толки тех же самых рецензентов о тех же самых книгах заставят его задуматься и приведут в недоумение. Та же самая неумеренность яв ялась в упреках сочинениям писателей, против которых рецензент питал ненависть или неблагорасположение. Так же безотчетно изАивац он гнев свой, удов етворяя минутному чувству.

2) Аитературное безверие и митературное невежество. Эти Ава свойства

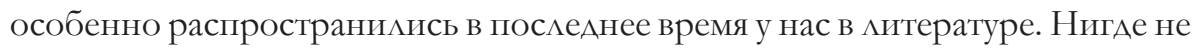
встретишь, чтобы упоминались имена уже окончивших поприще писателей наших, которые глядят на нас в мучах славы с вышины своей. Ни один из критиков не подня благоговейно глаз своих, чтобы их приметить. Никогда почти не стоят на журнальных страницах имена Аержавина, Аомоносова, Фонвизина, Богдановича, Батюшкова. Ничего о влиянии их, еще остающемся, еще заметном. Никогда они даже не брались в сравнение с нынешнею эпохой, так что наша эпоха кажется как будто отрублена от своего корня, как будто у нас вовсе нет начала, как будто история прошедшего Аля нас не существует. Это митературное невежество распространяется особенно межАу молодыми рецензентами, так, что вообще современная критическая митература совершенно похожа на наносную. Не успеет пройти год-другой, как толки, вначале довольно громкие, уже безгласные, неслышные, как звук без отголоска, как фразы, сказанные на вчерашнем бале. Имена писателей, уже упрочивших свою славу, и писателей, еще требующих ее, слелались совершенною игрушкою. ОАин рецензент роняет тех, которых подня его противник, и всё это Аелается без всякого разбора, без всякой идеи. Иное имя бывает обязано славою своею ссоре Авух рецензентов. Не говоря о писателях отечественных, рецензент, о какой бы пустейшей книге ни говорил, непременно начнет Шекспиром, которого он вовсе не читац. Но о Шекспире пошло в моду говорить - итак, подавай нам Шекспира. Говорит он: «С сей 
точки начнем мы теперь разбирать открытую пред нами книгу. Посмотрим, как автор наш соответствовац Шекспиру», а между тем разбираемая книга чепуха, писанная вовсе без всяких притязаний на соперничество с Шекспиром, и сходствует разве только с духом и образом выражений самого рецензента.

3) Отсутствие чистого эстетического наслаждения и вкуса. Еще в московских журналах видишь иногда какой-нибудь вкус, что-нибудь похожее

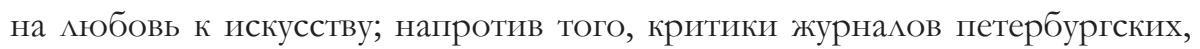
особенно так называемые благопристойные, чрезвычайно ничтожны. Разбираемые сочинения превозносятся выше Байрона, Гёте и проч.! Но нигде не видит читатель, чтобы это было признаком чувства, признаком понимания, истекло из глубины признате ьной, расстроенной Ауши. Слог их, несмотря на наружное, часто вычурное и блестящее убранство, Аышит мертвящею холодностию. В нем виАна живость или горячая замашка только тогАа, когда рецензент задет за живое и когАа дело относится к его собственному достоинству. Справедливость требует упомянуть о критиках Шевырева, как об утешительном исключении. Он передает нам впечатления в том виде, как приняла их душа его. В статьях его везде заметен; мыслящий человек, иногда увлекающийся первым впечатлением.

4) Мелочное в мыслях и мелочное щегольство. Мы уже вилели, что критика не занималась вопросом важным. Внимание рецензий было устремлено на целую шеренгу пустых книг и вовсе не с тем, чтобы разбирать их, но чтобы блеснуть мюбезностию, заставить читателя рассмеяться. Ао какой степени критика занялась пустяками и ничтожными спорами, читатели уже видели из знаменитого процесса о двух бедных местоимениях: сей и оный. Вот до чего дошла наконец русская критика!

Кто же были те, которые у нас говорили о митературе? В это время не сказац своих мнений ни Жуковский, ни Крылов, ни князь Вяземский, ни Ааже те, которые еще не так давно издавали журналы, имевшие свой голос и

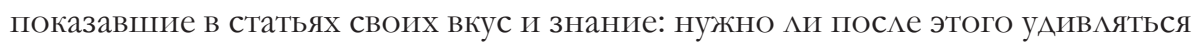
такому состоянию нашей митературы?

Отчего же не говорили сии писате и, показавшие в творениях своих

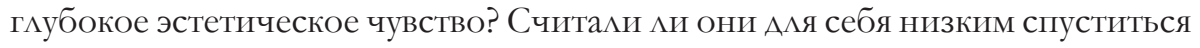
на журнальную сферу, где обыкновенно бойцы всякого рода заводят свой шумный бой? Мы не имеем права решить этого. Мы должны только заметить, что критика, основанная на глубоком вкусе и уме, критика высокого таланта имеет равное Аостоинство со всяким оригинацьным творением: в ней виден разбираемый писатель, в ней вилен еще более сам разбирающий. Критика, начертанная талантом, переживает эфемерность журнального существования. 
Аля истории митературы она неоценима. Наша словесность молода. Корифеев ее было немного; но Аля критика мыслящего она представляет целое поле, работу на целые годы. Писатели наши отлились совершенно в особенную форму и, несмотря на общую черту нашей митературы, черту подражания, они заключают в себе чисто русские элементы: и подражание наше носит совершенно северообразный характер, представАяет явление, замечательное Ааже Аля европейской митературы.

Но АОвольно. ЗакАючим искренним желанием, чтобы с текущим годом более показалось Аеятельности и при большем количестве журналов явилось бы более независимости от монополии, а через то более соревнования у всех соответствовать своей щели. По крайней мере заметно какое-то утешительное стремление уже и в том, что некоторые журналы с будущим годом обешают издаваться с большим противу прежнего рачением. Издатели Сына отечества, издатель Телескопа заговорили об улучшениях. Нельзя и сомневаться, чтобы при большем старании невозможно было сделать большего. По крайней мере, со всем чистосердечием и теплою молитвою изАагаем желание наше: да награАятся старания всех и кажАого сторицею, и чем бескорыстнее и добросовестнее будут труды его, тем более Аа будет он почтен заслуженным вниманием и благодарностию.

\section{Referências}

Caderno de Literatura e Cultura Russa número 1. São Paulo. Março, 2004.

DEBRECZENY, Paul. Social Functions of Literature: Alexander Pushkin and Russian Culture. Stanford University Press, California, 1997.

DRIVER, Sam. Puskin: Literature and Social Ideas. Columbia University Press, New York, 1989.

KAHN, Andrew. The Cambridge Companion to Pushkin. Cambridge University Press, 2006.

LÓTMAN, Iu. V chkole poetitcheskovo slova: Puchkin. Liermontov. Gogol': kniga dlia utchitelia. Prosveschenie, 1988.

PÚCHKIN, A. S. Sovriemennik, literaturnii jurnal, izdavaemii Aleksandrom Puchkinim. Poln. sobr. sotch.: v 10 t. - 1977-1979.

VINOGRADOV, V. V. Slovar' iazika Puchkina v 4 tomah. Azbukovnik, 2000. 